\title{
Assessment of Agricultural Options Available for Saving Orange Cultivation in Ribera Baixa (Valencia, Spain)
}

\author{
Alfred Wong $^{1} \&$ Enrique A. Navarro ${ }^{2}$ \\ ${ }^{1}$ Arbokem Inc., Vancouver, Canada \\ ${ }^{2}$ Instituto de Robótica y Tecnologías de la Información y Las Comunicaciones (IRTIC), Universitat de València, \\ Paterna (València), Spain \\ Correspondence: Alfred Wong, Arbokem Inc., Post Office Box 34173, Vancouver V6J 4N1, Canada. E-mail: \\ arbokem@arbokem.com
}

Received: October 6, 2013 Accepted: December 6, 2013 Online Published: January 22, 2014

doi:10.5539/jsd.v7n1p115 URL: http://dx.doi.org/10.5539/jsd.v7n1p115

\begin{abstract}
Orange cropping has been in practice in Ribera Baixa (Valencia, Spain) for several centuries. During the past decade, orange cropping has been under severe economic stress arising from increasing competition from less-costly foreign imports. Consequently, farm-gate prices are depressed, under the regime of fixed percentage distribution of retail pricing. Orange groves are being abandoned in many instances. A practicable and sustainable solution to this persistent economic problem would require a re-structuring of the marketing system to facilitate the sales of organic products and introduction of organic growing practices for oranges as well as secondary organic tree crops.
\end{abstract}

Keywords: farming economy, marketing, oranges, organic, Ribera Baixa, Valencia

\section{Introduction}

Orange (Citrus sinensis (L.) Osbeck), one of the most widely grown tree fruit crops in the World, is native to southern China. Cultivation of oranges in the western Mediterranean region began during the times of Al-Andalus (Watson, 1974; FSTC, 2012).

During the past few years, the orange cropping economy has been in significant decline as the farm-gate income covers the production costs only marginally at best. Rising input costs and foreign competition have been cited frequently to be the principal causes. Direct government subvention for orange growers has been solicited actively during the past few years (Anon, 2011).

Ribera Baixa is the most intensive orange-cropping area in the Valencia province. In recent years, many abandoned plots are filled with weeds and trash. And debris accumulated in the absence of maintenance increases the risk of fires during the dry summer months. Although orange farmers are starting to change their traditional practices such as diversification into the cropping of persimmon and pomegranate, and organic cropping, the underlying economic problem may remain unresolved. The prevailing structure of small holdings structure prevents consolidation to reduce production cost of traditional orange cropping.

This project was undertaken to examine the underlying causes of this decline and to devise possible remedies. Ribera Baixa was chosen as the study area.

\section{Methods}

Pubic-domain documents, including reports, statistics and journal publications were used for the present development and analysis of various scenarios for the remediation of the declining orange-cropping economy in Ribera Baixa.

Sample cropping cost data published by the Extension Service of the University of California for the Central Valleys, viz., Sacramento Valley and San Joaquin Valley, were used extensively for reference because of the considerable regional similarities in the climatic conditions and cropping practices between the Central Valleys (California) and Ribera Baixa. Figure 1 illustrates similar patterns of average incident solar radiation, temperature and precipitation. For the comparison of organic orange production, data from California's South Coast (e.g., Orange County and Riverside County) were also included. 
California agronomic data were adjusted on an as-required basis using the Consumer Price Index calculator published by the US Bureau of Labor Statistics (2013). The US currency was converted to Euro using reference values published by the European Central Bank (2013) for the indicated time. Typically, US-dollar cost or price was first adjusted for inflation, and then the inflation-adjusted value would be converted to Euros at the specified time period.

Except where noted, yield of oranges denotes saleable product, after sorting at packing houses.

\section{Results and Discussion}

\subsection{Orange Cropping}

Typically, full production of oranges starts at about 10 years after planting (Morton, 1987). The productive life of an orange tree might be 40 to 50 years (O'Connell, 2009). Stand management such as pruning and topping manually is only undertaken periodically throughout the life span of the stand.

Historically, orange production was not undertaken as monoculture over a large area in Ribera Baixa. Other tree crops such as almonds, olives and peaches were also grown. Application of fertilizers, pesticides and herbicides has become standard cultural practice in intensive monoculture cropping since 1970's.

\subsubsection{Comunitat Valenciana Production}

In 2010, Comunitat Valenciana produced $~ 1.51$ million tonnes of oranges (naranjo dulce), accounting for about $57 \%$ of the total orange production in Spain (IVE, 2012). The other two major producer regions are Andalusia and Murcia. The geographical locations of principal orange production areas within the Comunitat Valenciana are shown in Figure 2. Most of the oranges are grown in the province of Valencia. It may be noted that within the Comunitat Valenciana, most of the tangerines (mandarino) are grown in Castellón province. The province of Alicante has most of the production of lemon and lime (limonero).

The largest production area is La Ribera (comprising of Ribera Alta and Ribera Baixa) which account for more than $38 \%$ orange cropped area of Valencia, or about $28 \%$ of the entire Comunitat Valenciana (GVA, 2011). Table 1 shows that Ribera Baixa has the highest orange cropping intensity in the Comunitat Valenciana.

The principal varieties grown in Ribera Baixa are Navel-lane-late, Navelina and Valencia Late. Fresh oranges are effectively available year round except for July, August and September (GVA, 2010a).

\subsubsection{Inputs}

Oranges as well as other citrus fruits are harvested traditionally by hand (GVA, 2010a). The practice in California is not different (O'Connell et al., 2009). Figure 3 shows the comparative production costs for conventional oranges grown in California and in the Comunitat Valenciana. Labour cost is the largest cost component in both regions. 


\begin{tabular}{lll}
\hline$\multimap$ Sueca $(39.2 \mathrm{~N})$ & $\multimap-$ Sacramento $(38.6 \mathrm{~N})$ & $-\triangleright-$ Fresno $(36.8 \mathrm{~N})$ \\
$\multimap-$ Bakersfield $(35.4 \mathrm{~N})$ & $\multimap$ Riverside $(34.0 \mathrm{~N})$ & $-\times-$ Anaheim $(33.8 \mathrm{~N})$ \\
\hline
\end{tabular}
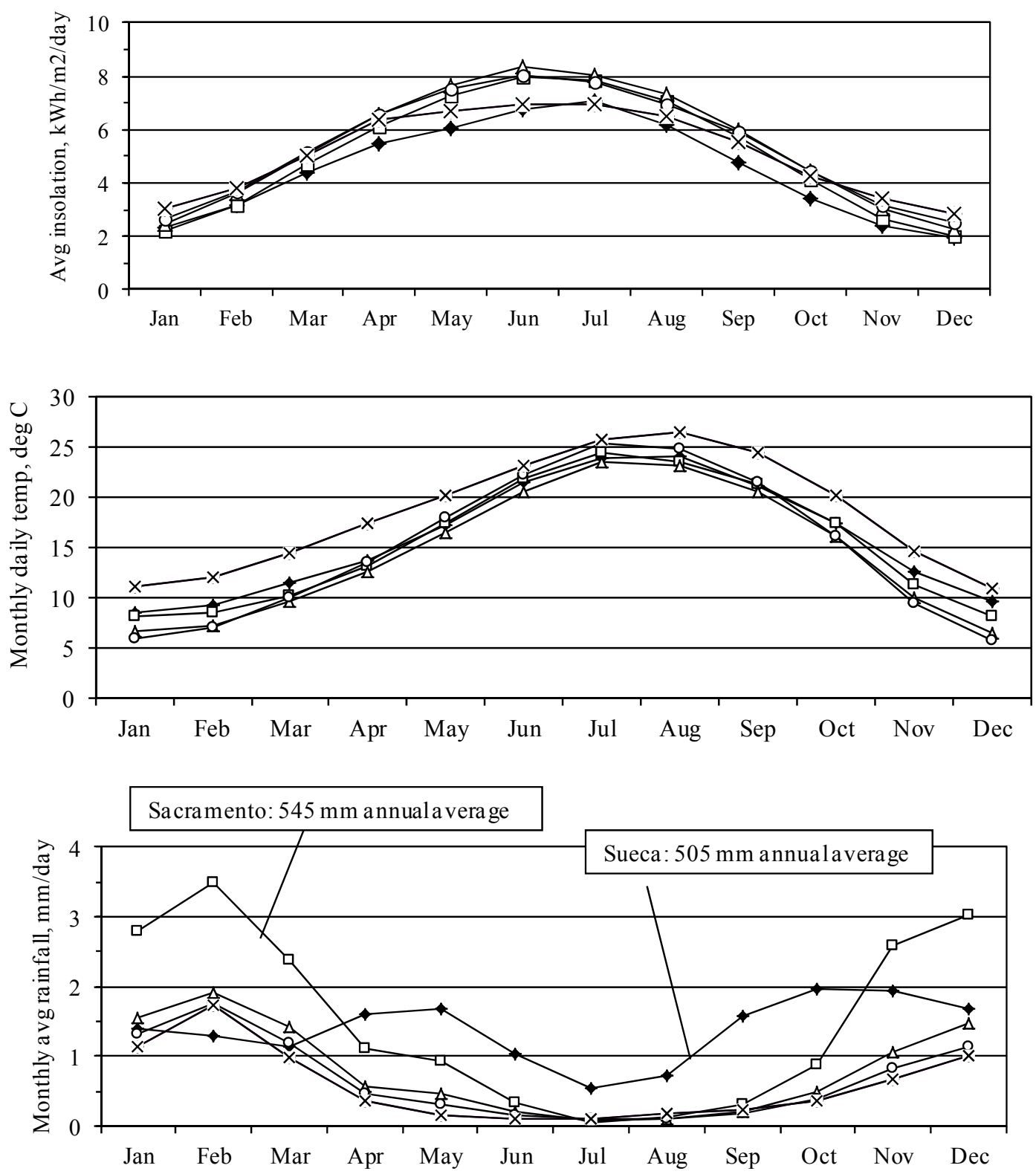

Figure 1. Selected meteorological characteristics

Source: ASDC, 2012. 


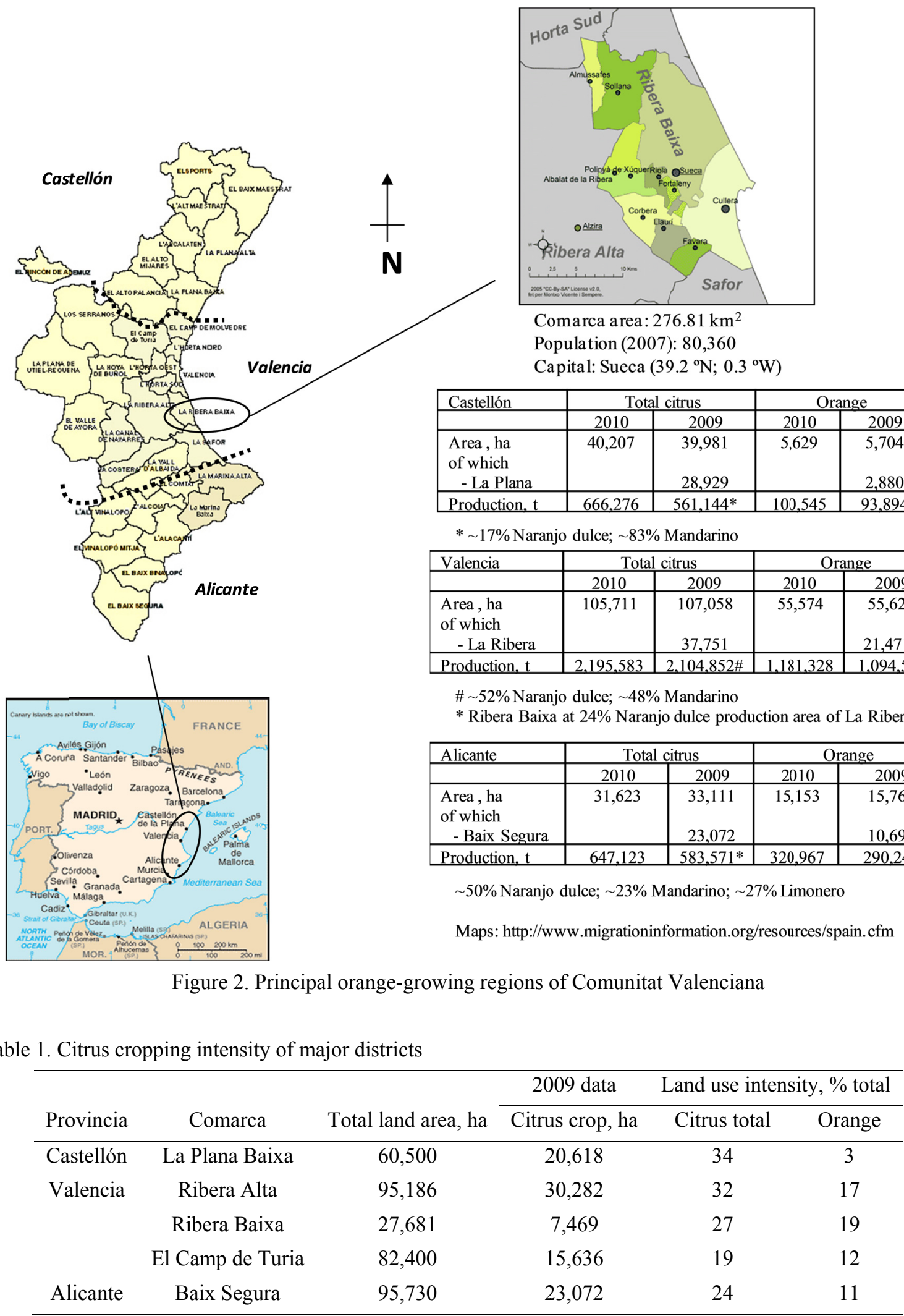

Source: GVA, 2010b. 


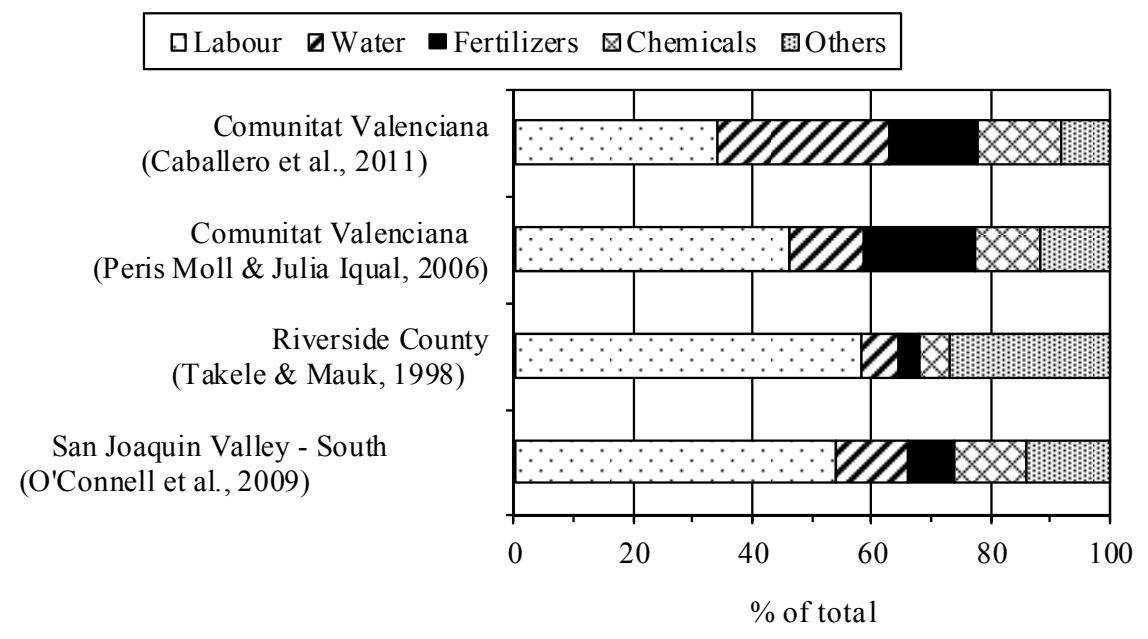

Figure 3. Comparative unit cost of conventional orange production

In Ribera Baixa, the required labour at the farm level may be contracted to farmers which specialize in among other things, planting, pruning, chemical application and picking. During the past decade, Spanish agriculture has become increasingly dependent on migrant labourers (principally from Africa) for its economic well-being. This agronomic situation is also very common in most developed countries (including USA and Canada) in which farm labour is a large component of production operations. There is no remedy as once-prevalent "unpaid" family labour in the Spanish citrus sector has largely become extinct. During the past few decades of economic prosperity in Spain, non-principal family members have better off-farm wage-paying work opportunities (Picazo Tadeo \& Reig Martínez, 2005). The underlying problem is that there is no place for an agrarian society in a developed economy.

In the regime of continuing globalization of freer trade, the market threat is expected to be more acute in coming years (Anon, 2012e). The underlying issue is that the basic wages of field workers paid by ex-EU competitors are substantially lower than those of Spain. The labour-cost offset deployed to date by Spanish producers has been to employ, legal as well as illegal, migrant workers from Africa and Latin America (Mendoza, 2001; Padilla \& Peixoto, 2007; Anon, 2010) at minimum wages or below.

Table 2 illustrates the substantial official wage gap for field workers between Spain and its 3 major competitors in the production of oranges. It is evident that the basic wage gap is too large to be narrowed. Moreover, there is certainly no guarantee that migrant farm workers are paid the minimum wage in the cited African countries. In Egypt, only government workers have a set minimum wage of International $\$ 5,680$ per year.

Table 2. Minimum wage scales of Spain and its top 3 competing countries in 2012

\begin{tabular}{ccccc}
\hline & Spain & Egypt & Morocco & South Africa \\
\hline International \$ per year* & 11,426 & Nil & 2,696 & 2,471 \\
$€$ per year (=€744.92 x 12 months) & 8,939 & --- & --- & --- \\
\hline
\end{tabular}

* "International dollar: is a hypothetical unit of currency that has the same purchasing power parity as that the U.S. dollar had in the United States at a given point in time (IMF, 2010).

Source: ILO, 2013.

\subsubsection{Market}

As shown in Figure 4, the production of oranges in Spain has nearly doubled since 1961, to nearly 2.9 million tonnes in 2012. The reported yield per hectare which has been relatively static should be considered to be saleable yield, i.e., after sorting for size, shape and other visual imperfections. For comparison, the field yield might be approximated to be $20 \%$ higher (O'Connell et al., 2009). Note the overall rapid expansion of orange harvested area during 1965-1970. Spain remains the largest producer of citrus fruits in the European Union. 
Table 3 shows that the Spanish share of fresh oranges in the UK market has varied between 20 to $30 \%$ by quantity, over the past 20 years. During the past decade, fresh oranges from Spain have been competing routinely against those imports from South Africa, Egypt and Morocco, in the UK market. About $20 \%$ of the Spanish orange production is diverted customarily for the production of orange juice in Spain as well as in other importing EU member states (USDA, 2012).

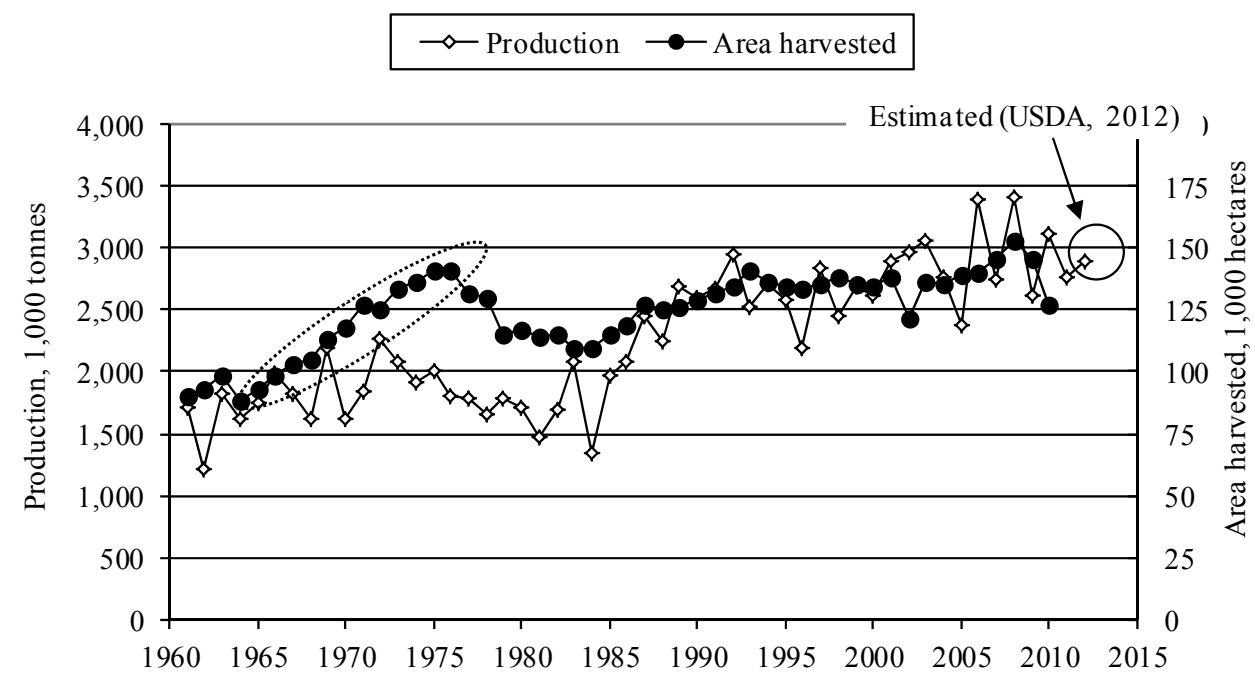

\begin{tabular}{llllllllllll}
\hline Yield & 2001 & 2002 & 2003 & 2004 & 2005 & 2006 & 2007 & 2008 & 2009 & 2010 & 10 -y avg \\
\hline $\mathrm{kg} / \mathrm{ha}$ & 20,989 & 24,398 & 22,318 & 20,397 & 17,124 & 24,258 & 18,788 & 22,227 & 17,929 & 24,471 & 21,290 \\
\hline
\end{tabular}

Sources: FAOSTAT, 2012; USDA, 2012.

Figure 4. Orange area harvested, production and yield in Spain

Table 3. UK importation of fresh oranges, 1990-2010

\begin{tabular}{cccccccccc}
\hline & \multicolumn{3}{c}{ Quantity, tonnes } & \multicolumn{2}{c}{$\begin{array}{c}\text { Landed value, } \\
\text { US } \$ 1,000\end{array}$} & \multicolumn{2}{c}{$\begin{array}{c}\text { Calculated value, } \\
\text { US } \$ / k g\end{array}$} & $\begin{array}{c}\text { \% ES share of UK } \\
\text { market }\end{array}$ & $\begin{array}{c}\text { Next 3 major } \\
\text { competitors }\end{array}$ \\
\cline { 2 - 10 } Year & Total & ES & Total & ES & Total & ES & Quantity & Value & By quantity \\
\hline 2010 & 275,646 & 68,395 & 211,457 & 63,900 & 0.767 & 0.934 & 25 & 30 & ZA, EG, MR \\
2005 & 339,733 & 75,459 & 213,964 & 54,389 & 0.630 & 0.721 & 22 & 25 & ZA, EG, MR \\
2000 & 316,774 & 94,582 & 141,606 & 54,343 & 0.447 & 0.575 & 30 & 38 & ZA, MR, IL \\
1995 & 321,692 & 69,317 & 164,316 & 34,980 & 0.511 & 0.505 & 22 & 21 & ZA, IL, MR \\
1990 & 390,441 & 78,780 & 205.798 & 36,702 & 0.527 & 0.466 & 20 & 18 & IL, MR, CY \\
\hline
\end{tabular}

$\mathrm{CY}=$ Cyprus; EG = Egypt; ES = Spain; IL = Israel; MR = Morocco; ZA = South Africa

Source: FAOSTAT, 2012.

With the EU signing of a freer trade agreement with Morocco in early 2012, it is now expected that the Moroccan shares of the EU citrus market (including the UK) would increase steadily in coming years (Anon., 2012a; Carrasco, 2012). Although the quality of Moroccan imports are considered to be presently lower than that of Valencia products, it is reasonable to expect that it would only be a matter time before this "inferior quality" issue is resolved.

\subsection{Economy of Orange Cropping in Ribera Baixa}

\subsubsection{Grove Size}

The average size of an orange farm in the Comunitat Valenciana has been reported to be about 3.35 hectares (Beltrán Esteve et al., 2012). However, the average size has also been cited to be less than 1 hectare (Peris Moll 
\& Juliá Iqual, 2006). Glick (1970) has noted that in 1963, more than 70\% of the land holdings in Valencia were less than 0.5 hectare. The actual average and range of size of holdings, particularly in Ribera Baixa, remain largely unclear. In Ribera Baixa, the average orange grove has been suggested to be only 0.3 hectare (Daniel Burguera, personal communication, 2013).

The La Ribera area, consisting of two sub-regions of Ribera Alta and Ribera Baixa, has been very valuable and productive since the 11th Century (Garrido, 2007). In successive generations, the land holding was also divided among the sons to result in substantial fragmentation of orange groves in present days. In the 1930s, a land holder of 4 hectares was considered to be wealthy (Brenan, 1950). The economy then was that the value of one arroba $(=12.5 \mathrm{~kg})$ of oranges was sufficient to pay one day's salary of a worker. The common land unit in Valencia was the hanegada. One hanegada (=1/12 hectare) producing 300 arrobas of oranges was sufficient to provide sustaining income for one family. Although some smaller $100 \%$ self-worked farms are continuing in Ribera Baixa, their economic viability is considered to be largely marginal. In present day, the gross income has become too small to sustain a family unit. Supplementary off-farm paid work has become an economic necessity.

Because citrus production became very profitable during the 1960s-1970s, citrus farming was extended to other places where water was scarce or expensive. In Ribera Baixa, old cropping practices were abandoned as olive, almond and peach trees were replaced with citrus trees. Calatayud i Giner (1989) had chronicled the mixed farming practice in La Ribera up until the 1930s. Wheat was even grown in the area until the early 1950s (Daniel Burguera, personal communications, 2013).

In present day Ribera Baixa, a full time farmer may crop several non-contiguous small plots, owned or rented, for achieving a minimum level of personal income. The classical approach of amalgamation of small holdings into a single large contiguous unit for improved productivity would not be workable for this fragmented structure of multiple small holdings. Agustí (2002) had proposed a political-technical solution to consolidate holdings and cooperatives, with the ultimate aim to reduce mechanization costs. Over the years, the Generalitat has promoted such a "land consolidation" policy with little or no success.

\subsubsection{Water Supply}

During the summer months, citrus orchards need to be irrigated in this arid zone of Spain. Availability (and affordability, to a lesser extent) of water is steadily becoming a critical issue. The three major rivers of the Comunitat Valenciana, viz., Túria, Xúquer and Segura, are essentially delivering water at their maximum capacities. The irrigation of Ribera Baixa fields is based largely on water drawn from the Riu Xúquer. In contrast, in Ribera Alta, groundwater and/or well water is pumped to irrigate the fields. The practice of deficit irrigation (Gasque et al., 2010; Ruiz Sanchez et al., 2010) is being promoted as a good water conservation practice. The last potential under-utilized water supply is recycling treated wastewater at least for irrigation purposes (Alcon et al., 2010).

In Ribera Baixa, irrigation is also made, to a large extent, by gravity flow in water channels (acequias) for the delivery of water to the orchards. This 1,000-year old mode of irrigation (Glick, 1970; Bolens, 1972) has been very efficient as all irrigation water is used. Water leaking in flows through water channels (escorrentias) is directed for use in the rice fields or Albufera lagoon area.

Historically, water rights are attached to the land in this region (Glick, 1970). In comparison, large citrus groves such as the 600-hectare "El Realengo" citrus orchard in Rafelguaraf (Ribera Alta) are located far from the coast in more arid areas where there was no gravity irrigation. Prior to the 1960s, almond, olive and other dryland (secano) crops were farmed. Because of low productivity, large land parcels, largely unwanted then, were maintained without extensive fragmentation. In the present time, irrigation (including drip irrigation via pumping from wells) has changed the subsistence farming (of these larger farms) into industrial farming.

\subsubsection{Farm-Gate Economy}

As shown in Figure 5, the producer (farm-gate) price of Spanish oranges had been hovering at the level of about $€ 0.20$ per kg throughout 2011. In 2012, the average farm-gate price has been only $€ 0.15$ per $\mathrm{kg}$, well below those for the First Quarter in the previous 2 years. For Ribera Baixa orange producers, the current cost of production is about $€ 0.25$ per $\mathrm{kg}$, and the selling price at the farm-gate has been at best $€ 0.24$ per $\mathrm{kg}$ (Daniel Burguera, personal communication, 2013). It has also been commented that the transacted year-end orange farm-gate price was only $€ 0.16$ per $\mathrm{kg}$. 

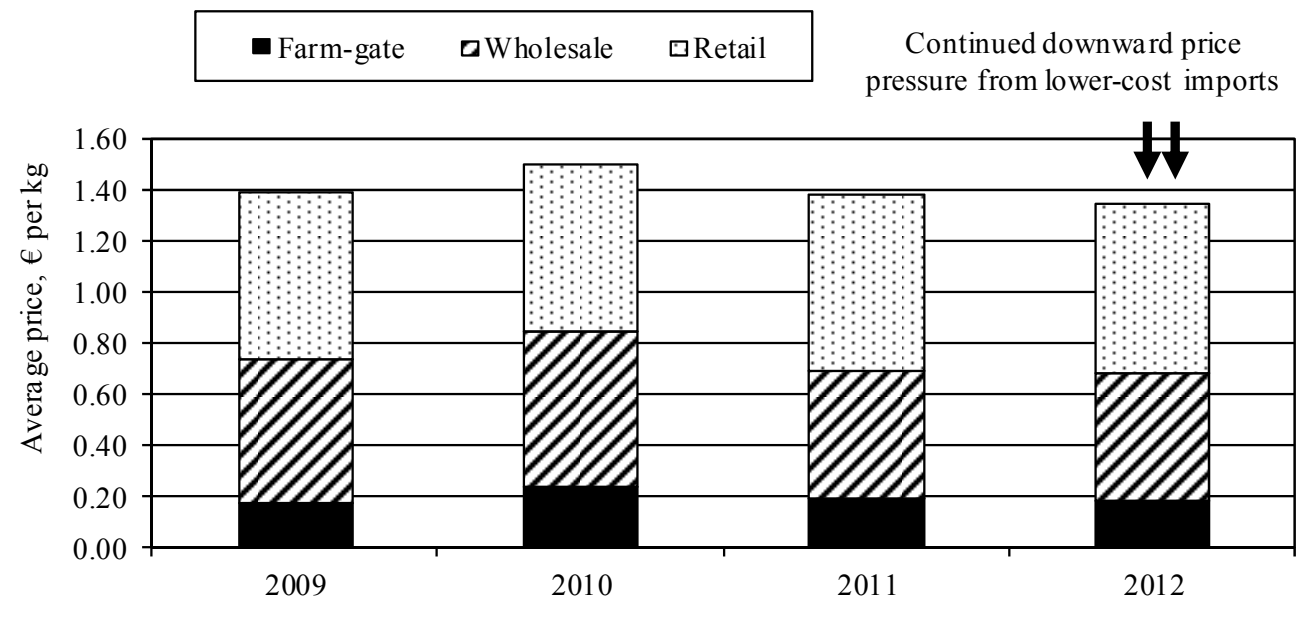

Adapted from USDA, 2011; USDA, 2012.

Figure 5. Average annual prices of navel oranges in Spain along different levels of the supply chain

The problem of lower retail prices is attributed to, among other things, increased duty-reduced importation of oranges from North Africa, Middle East and South America into the EU as well as the market penetration by foreign producers into the traditional near-EU markets such as Ukraine (USDA, 2012).

Even with the economic recession in Spain for the past few years, the internal deflation has been insufficient to off set the increasing non-labour input costs such as fossil fuel, fertilizers and pest-control chemicals. In the recent past, conversion of orange groves to housing estates and golf course has been the easiest assured pathway to "instant" economic prosperity. But the real estate boom time is now over in eastern coastal Spain. Production of oranges has become increasingly unsustainable financially. The outlook for the continuation of orange farming in the Ribera Baixa area, indeed perhaps the entire Comunitat Valenciana, is somewhat dismal (Anon., 2012f, 2012h, 2012i). Indeed some orange groves have been reported to be simply abandoned by the farmers in the Comunitat Valenciana (Anon., 2012c, 2012g; USDA, 2012).

\subsection{Alternatives Production Strategies}

\subsubsection{Tree Nut Crops}

\section{Almonds}

Almond (Prunus dulcis (Mill.) D.A. Webb) is a well-established crop in Spain. In 2010, Spain ranked as the second largest producer after the USA, with a production of 220,000 tonnes (FAOSTAT, 2012). Almonds have been grown in Ribera Baixa decades ago. Its re-introduction may however be problematic in view of the large commercial production by others elsewhere in Spain presently. However, a small production of organically-grown almonds might be of significant economic value (Holtz et al., 2007). The target markets in the EU would be Germany and the UK where the public eco-consciousness is notably high.

\section{Pistachios}

Pistachio (Pistachia vera L.), a desert plant, could be an alternative tree crop in place of traditional oranges in Ribera Baixa. It has a wide temperature-tolerant range from $-10{ }^{\circ} \mathrm{C}$ to $40{ }^{\circ} \mathrm{C}$. Significant biennial production is achieved in 7 to 10 years, after orchard establishment. It is interesting to note that pistachio cropping was started in the San Joaquin Valley in California (USA) only in about 1975. Thirty years later, California production (accounting for more than $98 \%$ of commercial production in the USA) was $\sim 237,000$ tonnes, ranking second behind Iran's production of $\sim 445,000$ tonnes. The total global production in 2010 was reported to be about 944,000 tonnes (FAOSTAT, 2012). Interestingly, USA is not a major supplier of pistachios to the UK. Within the EU, Greece has been the sole producer until the entry of Cyprus in 1978 and Italy in 1985. Both Italy and Greece were producing about 9,000 tonnes each in 2010 (FAOSTAT, 2012). It may be noted that the Sicilian "Pistacchio di Bronte" and Greek "Aegina Fistiki" pistachios have the important Protected Designation of Origin (PDO; EC Directive 1263/96), which afford certain premium pricing in the EU market. Spain is not known to have any significant commercial production of pistachios presently. In 1995, small-scale commercial production of pistachios were introduced in Castilla-La Mancha, Aragon, Extremadura and Andalucia regions, in substitution of other tree nut crops such as almonds. For example, in 2001, Lleida has about $30 \%$ of the 
1,000-hectare pistachio plantation area of Spain. Successful commodity-scale production of pistachios depends, among other things, on selected cultivars for resilience under different climatic and soil conditions. Sueca (Ribera Baixa) has lower average annual rainfall than Lleida. The average temperature and relative humidity patterns of both localities are not substantially different.

Most of the Italian pistachios are grown in Bonte (Catania) at about $700 \mathrm{~m}$ altitude where farm land for tree cropping is available. The most well-known Greek pistachio plantation area is on the island Aegina, a small $87-\mathrm{km}^{2}$ island located about $25 \mathrm{~km}$ south of Athens. Pistachio has been grown in Aegina for nearly 100 years. The meteorology data showed that a) the average daily temperature of Aegina (and Bonte) generally warmer than Sueca, and b) the average rainfall and relative humidity of Aegina (and Bonte) about the same as Sueca. Thus, there are no known a priori reasons as to why pistachios could not be grown successfully in Ribera Baixa, especially if the practice was undertaken in a small organic cropping scale.

Based on a representative yield of $1,765 \mathrm{~kg}$ per hectare and farm-gate price of $€ 9.06 / \mathrm{kg}$ reported for pistachio production in Greece in 2010 (FAOSTAT, 2012), the estimated farm-gate income of PDO pistachios could be nearly $€ 16,000$ per hectare in Ribera Baixa. In contrast, the average farm-gate value of oranges in Spain was only $\sim 66,100$ per hectare at a yield of $24,471 \mathrm{~kg}$ per hectare and a farm-gate price of $€ 0.248$ per $\mathrm{kg}$ (FAOSTAT, 2012). An analysis of the sample cost for pistachio production in California, i.e., San Joaquin Valley - South (Beede et al., 2008) is particularly instructive. Upon updating the production cost from 2008 to 2012, and converting US\$ to $€$ at the nominal exchange rate of US\$1.25 per $€$, the total production cost is estimated to be $€ 7,784$ equivalent per hectare, and the gross revenue would be $€ 9,594$ equivalent per hectare. The gross margin of pistachio production would certainly be substantially higher than that for orange cropping achieved during the past few years. This promising outcome suggests that the prospective pistachio cultivation in Ribera Baixa is worthy of a detailed investigation.

The UK market is of particular interest, with an average (1990-2010) importation of about 6,300 tonnes of pistachios annually at an average value of about US $\$ 4.15$ per $\mathrm{kg}$. See Table 4 . Organically-grown pistachios are rarely available from major producers. Such a product could be expected to realize significantly greater value in the UK market.

Table 4. UK importation of pistachios, 1990-2010 selected data

\begin{tabular}{|c|c|c|c|c|}
\hline Year & $\begin{array}{l}\text { Quantity, } \\
\text { tonnes }\end{array}$ & $\begin{array}{l}\text { Landed value, } \\
\text { US } \$ 1,000\end{array}$ & $\begin{array}{c}\text { Calculated } \\
\text { value, U\$/kg }\end{array}$ & Comments \\
\hline 2010 & 3,554 & 32,086 & 9.03 & $\begin{array}{l}\text { Germany and Netherlands (combined } 45 \% \\
\text { market share; probable product origin was Iran) }\end{array}$ \\
\hline 2005 & 11,096 & 32,451 & 2.92 & $\begin{array}{l}\text { Netherlands }(58 \% \text { of market share; probable } \\
\text { product origin was Iran) }\end{array}$ \\
\hline 2000 & 5,257 & 21,342 & 4.06 & $\begin{array}{l}\text { Germany ( } 81 \% \text { market share; probable product } \\
\text { origin was Iran) }\end{array}$ \\
\hline 1995 & 6,883 & 23,522 & 3.42 & Iran $(73 \%$ market share $)$ \\
\hline 1990 & 4,881 & 22,177 & 4.54 & Iran $(82 \%$ market share $)$ \\
\hline Avg & 6,334 & 26,316 & 4.15 & Simple $1990-2010$ average \\
\hline
\end{tabular}

Source: FAOSTAT, 2012.

Table 5 shows that the consumption of water for selected tree crops. One important factor of importance is that Ribera Baixa has an annual rainfall of about $500 \mathrm{~mm}$ (ASDC, 2012). Unlike other drier orange cropping regions of Comunitat Valenciana, irrigation of orange groves in Ribera Baixa is undertaken sparingly only during the very dry summer months. Thus, the net irrigation water demand for orange cropping in Ribera Baixa would be substantially less than the values cited by Ribal et al. (2009). Note that the water demand for pistachio cropping could be as much as 1.4 times higher than that for orange cropping, at the same reference location of San Joaquin Valley - South. Even with a likely off-set of about $5,000 \mathrm{~m}^{3} /$ ha from natural precipitation, this undertaking of pistachio cropping should be approached cautiously in view of the potentially higher water requirement. It is recognized that pistachios grow best in dry climatic conditions, including lower air humidity. In view of the prior 
history of successful almond cropping in Ribera Baixa, pistachio cropping could also be practicable, despite the "slightly wetter conditions" arising from its close proximity to the Mediterranean Sea.

\subsubsection{Organically-Grown Products}

Within the framework of the 2003 Common Agricultural Policy, organic farming is promoted by the EC through, among other programs, the "European Agriculture Fund for Rural Development" (EC, 1999; Peris Moll \& Juliá Igual, 2003; Peris Moll et al., 2005; Bonny, 2006; Lehner, 2010). The production and labeling of organic products are regulated in the EU $(\mathrm{EC}, 2007)$.

Table 5. Comparative demand of irrigation water of selected tree crops

\begin{tabular}{cccc}
\hline Crop & Location & Reference & $\mathrm{m}^{3} / \mathrm{ha} /$ year \\
\hline Almonds - Organic & San Joaquin Valley - North & Holtz et al., 2007 & 10,670 \\
Almonds & Sacramento Valley & Connell et al., 2012 & $9,652^{*}$ \\
Moringa & Ribera Baixa (prospective) & ----- & Zero\# \\
Olives (table) - Manzanillo var. & Sacramento Valley & Ferguson et al., 2009 & $9,144^{*}$ \\
Oranges - Valencias & Riverside County & Takele \& Mauk, 1998 & 12,192 \\
Oranges - Navels/Valencias & San Joaquin Valley - South & O'Connell et al., 2009 & 7,620 \\
Oranges - Navelina & Comunitat Valenciana & Ribal et al., 2009 & $5,000-6,000$ \\
Peaches (July-August harvest) & San Joaquin Valley - South & Day et al., 2009 & 11,176 \\
Peaches (cling, late harvest) & San Joaquin Valley & Norton et al., 2011 & 10,668 \\
Peaches (cling, extra early) & San Joaquin Valley & Duncan et al., 2011 & 9,144 \\
Pistachios & San Joaquin Valley - South & Beede et al., 2008 & 10,670
\end{tabular}

* plus $3,048 \mathrm{~m}^{3} /$ ha from rainfall expected in the winter months in the Sacramento Valley. The average annual rainfall in Sacramento (city) is $545 \mathrm{~mm}$.

\# probably sufficient from average annual rainfall of $\sim 500 \mathrm{~mm}$ in Sueca (Ribera Baixa).

The public interest in purchasing organic food products is growing steadily as supply becomes more prevalent (Jánský et al., 2004; Jánský \& Živělová, 2007; DG Environment, 2009). The driving force appears to the consumers' self-interest for better personal health (Wier et al., 2005), instead of the protection of the broader environment from destructive agricultural practices (Lillywhite et al., 2012; Swagemakers et al., 2012). The prospect of premium pricing is a critical driving force for farmers to undertake organic farming practices (Beltrán Esteve et al., 2012). There are also instances in which farmers will undertake voluntarily to organic farming because of the extensive use of pesticides and herbicides is harming the health of all farm workers. In monoculture cropping, there is always a constant need to use ever more potent pest control chemicals. Conversion of conventional farming to organic farming will require significant effort and determination from farmers (Nettier et al., 2012).

Increase in organic market in the EU will certainly attract competitive supplies from non-EU countries (Kamp, 2008). However, this problem may be mitigated. To a certain extent, the EU organics (including oranges) market is still largely unfulfilled and the "Valencia" provenance could be deployed as an effective marketing feature.

Organic orange cropping has been suggested as a value-added opportunity. But this approach has been assessed to be uneconomical under the small-farm circumstances of Valencia (Peris Moll \& Juliá Iqual, 2006). Figure 6 shows the comparative costs of organic orange production in California and in the Comunitat Valenciana. Note that the labour cost component is largely the same in both locations. Peris and Juliá (2006) have cited that the shortage of approved organic fertilizer is a substantial cost factor in the Navelina cropping in the Comunitat Valenciana. There is an abundant source of rice straw uniquely available in Ribera Baixa for composting into soil fertilizer. More than 30,000 tonnes of surplus straw available annually from rice cropping activities in the Albufera wetlands of Ribera Baixa (Modesto et al., 2005) could be composted to provide the required economical "natural" fertilizer. The technology of composting rice straw, with and without additional nitrogen sources, is generally known (See, for example, Daly, 2002; Luu et al., 2002; Iranzo et al., 2004; Roca-Peréz et al., 
2004; Ciaccia et al., 2008; Tran et al., 2008). Moreover, there is already direct field experience in the composting of rice straw in the Valencia province (Ayuntamiento de Valencia, 2004).

Alternatively, moringa cultivation could be undertaken as an intercrop to provide nitrogen-rich leaves for the preparation of rice straw-based compost for qualification as an organic fertilizer for the growing of oranges and pistachios (Navarro \& Wong, 2013).

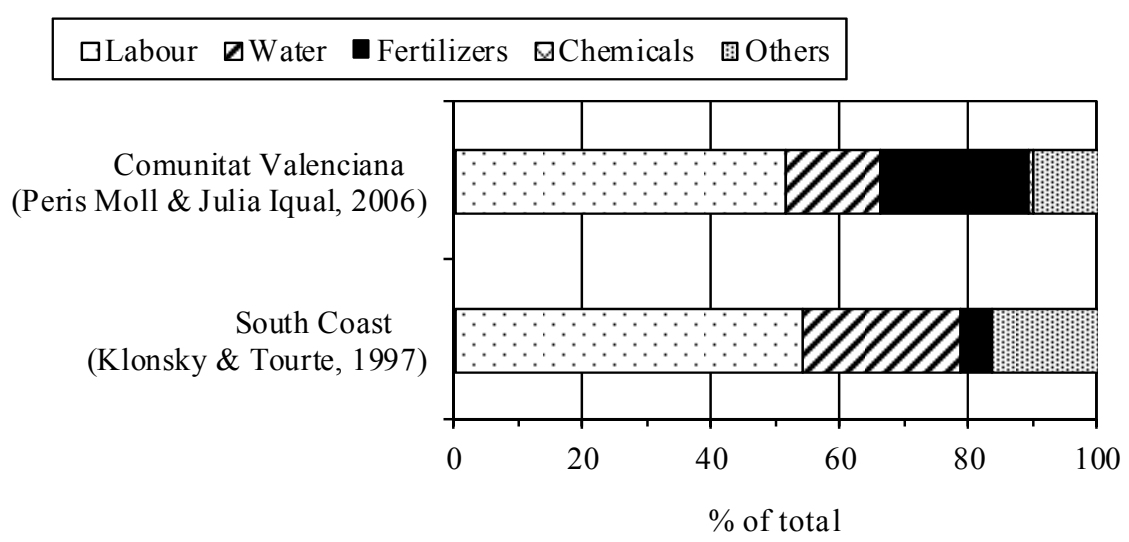

Figure 6. Comparative unit cost of organic orange production

\subsubsection{Direct Marketing}

The traditional and alternative means of marketing oranges are illustrated in Figure 7. The classical approach affords inequitable distribution of wealth to the growers. The majority of the produce value is retained by the distributors (wholesalers) and the retailers. Figure 8 shows that the share of the retail price retained by the growers has been in the range of 12 to 16\% during the period of the 2009 to 2011. In the First Quarter, 2012, the grower had retained just average $12 \%$ of the retail price. In absolute terms, the farm-gate price had fallen to average $€ 0.15$ per $\mathrm{kg}$. It is recognized that in the low-price retail market, all parties earn less. Note that the margin retained by each of the three margins is essentially unchanged. But in the case of growers, the lower income could reach a critical level in which the orange-growing operation becomes financially unsustainable. It is evident that an alternative means to achieve a more equitable revenue distribution is acutely needed.

This pattern of wealth distribution is interestingly similar to that of export-oriented producers of bananas and fresh vegetables in low-wage countries (Wong \& Hallsworth, 2013). In essence, the fixed-proportion revenue distribution regime could not provide any enduring improvements to the orange farming economy as reduction in production costs has reached the practical limit. An alternative marketing scheme is needed.

Even with declining retail prices, the wholesalers and retailers still retain the largest portion of the total revenue. Because of the structure of market control by the major retailers, the mark-up by the retailers could not be altered. The retailer will retain its customarily 45 to $50 \%$ of the retail price revenue. The "wholesaler" would be the only place where a re-structuring could shift a larger portion of the remaining revenue to the grower. In order to reduce the wholesaler's margin, Ribera Baixa growers would need to implement alternative ways and means to sell directly, with just-in-time delivery of goods from Valencia to the retailer. In any market re-structuring scenario, the retailer can be expected to maintain the same gross revenue as a fixed \% of retail price. This outcome of direct marketing can be expected even if the retailers were smaller specialty stores which are more inclined to consider selling organic produce with well-defined "attractive provenance and ecological production basis".

Moreover, direct marketing is the only effective and durable defense against "low-price imports based on cheap labour". In essence, direct marketing assures a more equitable economic return for the farmers. 


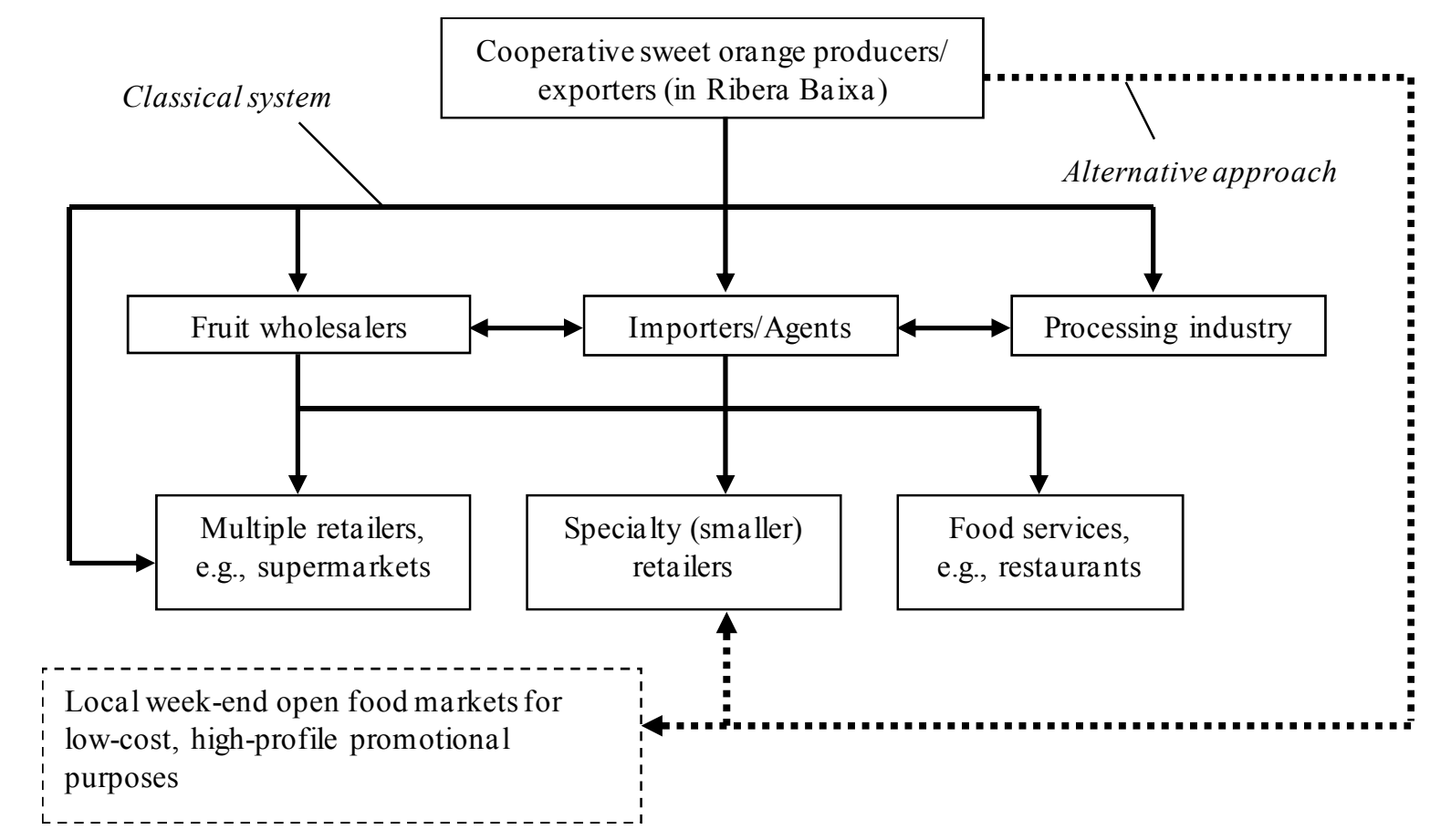

Adapted from CBI, 2006

Figure 7. Example trade pattern of oranges from Comunitat Valenciana to the UK

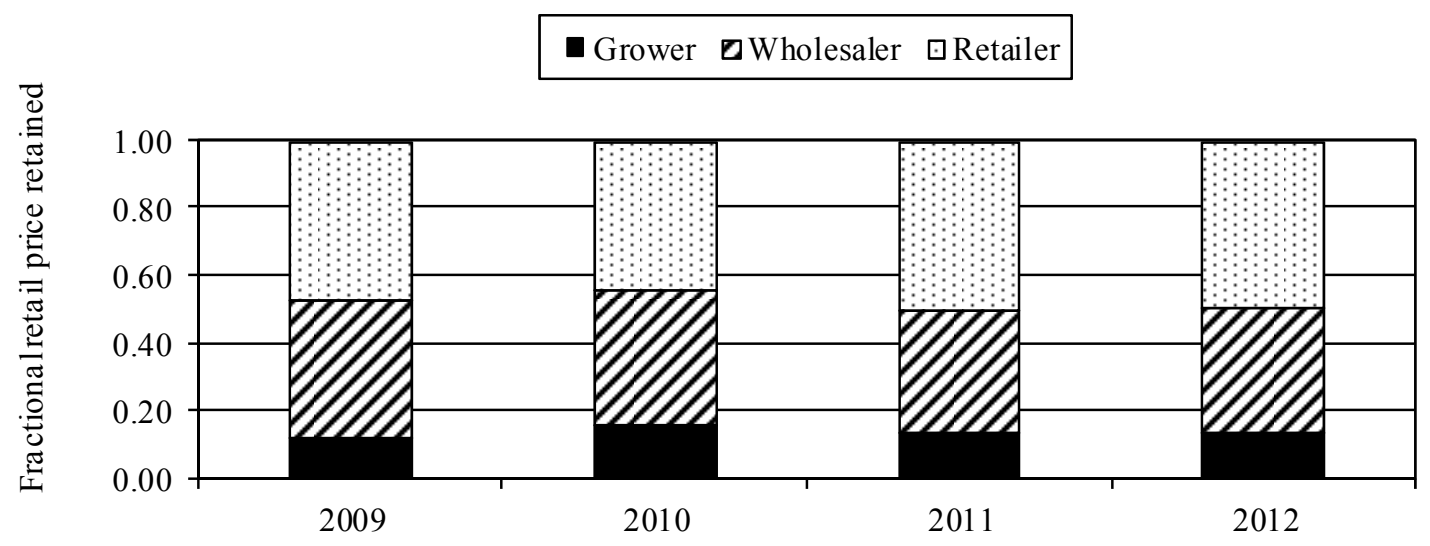

Adapted from USDA, 2011; USDA, 2012

Figure 8. Average annual fresh Navel orange revenue distribution at different levels of the supply chain in Spain

Additional opportunities to promote the sale of fresh organic oranges and organic pistachios from Ribera Baixa farmers could be realized through sales in weekend farmers' market in south England, for example. The weekend farmers' market approach is a low-risk approach and it is directed largely to eco-conscious consumers who have sufficient disposable income for the purchase of healthier fresh food. This approach would of course require a concerted transition to organic farming and diversification in the former monoculture orange groves.

Some orange farmers are attempting to sell oranges directly via the Internet (Anon., 2012b). But the cost structure is highly unfavourable as oranges are very "heavy weight, low value" goods for economical shipping in small quantities. The cost of shipping might be as much as the cost of goods.

Other farmers have tried diversification into growing specialty tree crops such as persimmon, pomegranate, etc. (Anon., 2012d). This strategy does not appear to be very practical as intrinsic demand for persimmons and pomegranates is quite small in Europe. The export market is already dominated by low-cost producers in China and other low-wage countries. In the case of persimmons, China already has $75 \%$ of the World's production of $\sim 4$ million tonnes in 2010 (FAOSTAT, 2012). See Figure 9. It has been reported that about 95\% of Spain's 
production of about 80,000 tonnes of pomegranates has already been "absorbed" in the EU states outside of Spain (AMAIL, 2012). Even if persimmons and pomegranates produced in Ribera Baixa could be marketed without any limitations, the underlying problem remains the same, i.e., the retailers and distributors will retain the most of the retail value of these products. In essence, the growers would encounter the same problem as orange production, in the longer term.

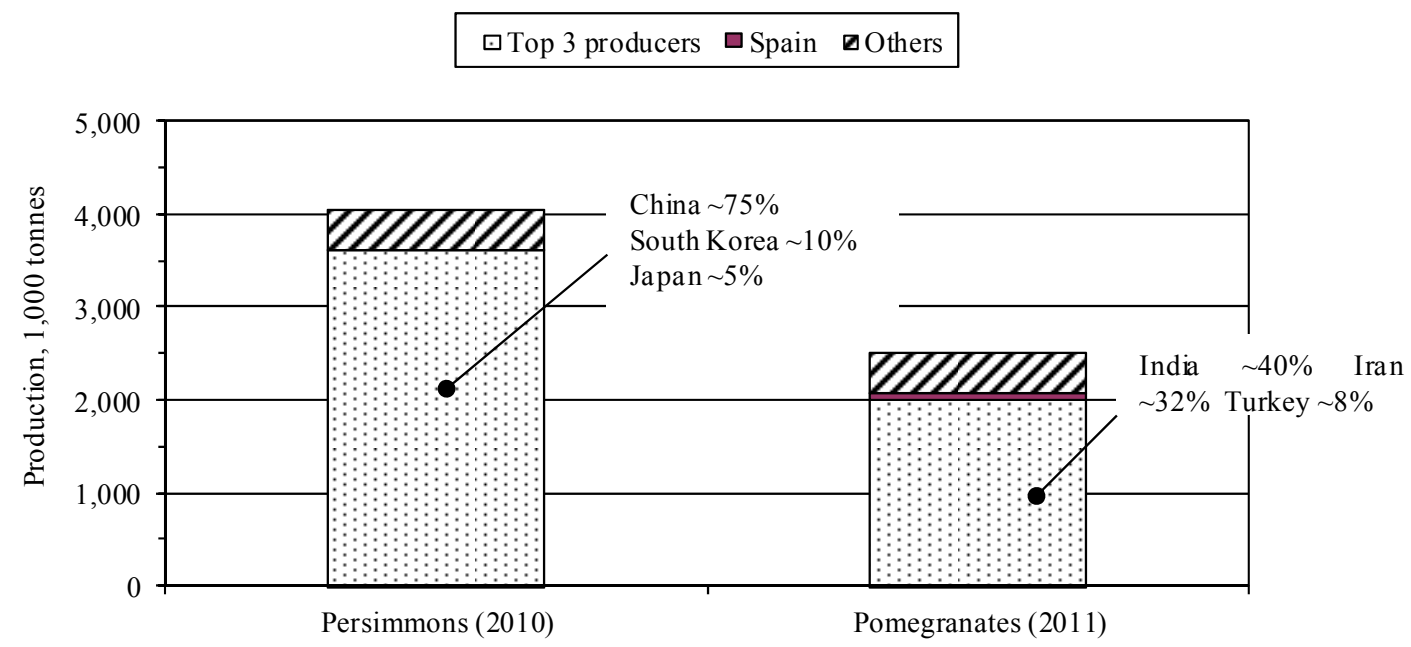

Sources: Persimmons: FAOSTAT, 2012; Pomegranates: AMAIL, 2012.

Figure 9. Global production of persimmons and pomegranates

\subsection{Path Forward}

Continuation of orange cropping in Ribera Baixa requires a different strategy of sustainable development involving new marketing and crop production models. The foremost undertaking is the establishment of a new direct marketing regime to shift more cash margin to the growers. Otherwise, the same unsatisfactory net farm-income would prevail because of the fixed inequitable distribution of retail product value. This situation applies during the high and as well as the low price market. Rapid transition to organic cropping and additional diversification to pistachios or other crops could then follow. Direct marketing is an essential first step to permit the effective positioning of Ribera Baixa's organically grown produce into the desired group of consumers in the UK market. It may be noted that the availability of organic pistachio is still a rarity in the market place. Moreover, large scale producers, especially those located in low-wage countries, are expected to have considerable difficulties in shifting production from commodity grades to organic grades. For small individual producers in Ribera Baixa, there is essentially no future in the commodity orange business.

Table 6 summarizes the analysis of the options available for the re-structuring of orange cropping in Ribera Baixa. It is evident that selling organic oranges through conventional marketing channel does not afford any increase in economic viability. Peris Moll and Juliá Iqual (2006) had concluded that organic cropping to be an economically unattractive option. Compare non-organic Scenario "A" and organic Scenario "B" in Table 6. Note the economic attractiveness of organic Scenarios " $C$ " and " $D$ ". 
Table 6. Preliminary economics of proposed new cropping regime

\begin{tabular}{|c|c|c|c|c|c|c|}
\hline Reference & \multicolumn{2}{|c|}{$\begin{array}{l}\text { Peris Moll \& Julia Iqual, } 2006 \text { (data } \\
\text { from 2003-2004 season) }\end{array}$} & \multicolumn{4}{|c|}{ This work (a) } \\
\hline Scenario & $\mathrm{A}$ & B & \multicolumn{2}{|c|}{$\mathrm{C}$} & \multicolumn{2}{|c|}{$\mathrm{D}$} \\
\hline Product & Navelina & Navelina & Navelina & Pistachio & Navelina & Pistachio \\
\hline Cropping system & Standard & \multicolumn{5}{|c|}{ Organic } \\
\hline Land allocation, ha & 1.0 & 1.0 & 0.9 & 0.1 & 0.9 & 0.1 \\
\hline Yield, kg/ha & 42,229 & 30,187 & 30,187 & $2,243(b)$ & 30,187 & $2,243(b)$ \\
\hline Farm-gate price, $€ / \mathrm{kg}$ & 0.15 & 0.26 & 0.26 & $4.38(\mathrm{c})$ & 0.26 & $4.38(\mathrm{c})$ \\
\hline $\begin{array}{l}\text { New marketing margin, } \% \\
\text { of base farm-gate price }\end{array}$ & 0 & 0 & 50 & 50 & 100 & 100 \\
\hline $\begin{array}{l}\text { Extra income from new } \\
\text { marketing regime, } € / \mathrm{kg}\end{array}$ & 0 & 0 & 0.13 & 2.19 & 0.26 & 4.38 \\
\hline $\begin{array}{c}\text { Total farm-gate price, } \\
\qquad / \mathrm{kg}\end{array}$ & 0.15 & 0.26 & 0.39 & 6.57 & 0.52 & 8.76 \\
\hline Gross production, $\mathrm{kg}$ & 42,229 & 30,187 & 27,168 & 224 & 27,168 & 224 \\
\hline $\begin{array}{c}\text { Gross farm-gate revenue, } \\
€\end{array}$ & 6,334 & 7,849 & 10,596 & 1,474 & 14,128 & 1,965 \\
\hline Total production cost, $€$ & $3,582(d)$ & $5,889(\mathrm{e})$ & $5,300(\mathrm{f})$ & $643(\mathrm{e})$ & $5,300(\mathrm{e})$ & 643 (f) \\
\hline Net farm-gate income, $€$ & 2,752 & 1,960 & & & & 149 \\
\hline
\end{tabular}

Notes: 2004 base year used for illustration purposes

(a) All 2008 data of Beede et al. (2008) adjusted to 2004 base year using the procedure described earlier in the "Methods" section. US Consumer Price Index: US\$1.00 in $2008=$ US $\$ 0.88$ in 2004; ECB exchange rate: US\$1. $2439=€ 1.00$ in 2004.

(b) Applying same $29 \%$ decrease from reference conventional yield for Navelina (Peris Moll \& Juliá Iqual, 2006) to reference $3,138 \mathrm{~kg}$ pistachio yield per hectare (Beede et al., 2008).

(c) Applying same $26 \%$ increase in reference price for Navelina (Peris Moll \& Juliá Iqual, 2006) to reference price of $€ 3.06$ per $\mathrm{kg}$ pistachio (Beede et al., 2008)

(d) Excluding depreciation and opportunity costs (Peris Moll \& Juliá Iqual, 2006)

(e) Excluding depreciation and opportunity costs (Peris Moll \& Juliá Iqual, 2006); notwithstanding the high cost of organic fertilizers used

(f) Including capital recovery (calculated from Beede et al., 2008)

\section{Concluding Remarks}

The problem of orange cropping in Ribera Baixa is persistent and difficult to solve in view of continued globalization of freer trade with competitive fresh oranges arriving into the EU from low-wage producing countries. Incremental gains in productivity could not overcome the structural problems. The fragmented holding structure of orange groves in Ribera Baixa offers an interesting opportunity to devise a practicable and sustainable solution. The essential rectification steps might include a) implementation of an alternative direct marketing system to capture a higher proportion of the variable retail pricing, and followed by b) conversion to organic cropping with progressive phasing out monoculture practice with inter-cropping of novel tree nut crops such as pistachios. It is recognized that there is no assurance that the recommended remedial steps would ever be undertaken by orange growers, in view of the historical solutions applied to the recurring economic difficulties of orange farming in Spain. Short-term financial subvention by the government has been the standard practice in troubled economic times. 


\section{References}

Afghanistan Ministry of Agriculture, Irrigation and Livestock - AMAIL. (2012). Market Brief: Pomegranates, an overview of export potential. Paywand No. 5. Retrieved November 17, 2012, from http://paywand.mail.gov.af/Content/files/Market\%20Brief_PomegranatesOctober30.pdf

Agustí, M. (2002). La citricultura en la Comunidad Valenciana, evolución técnica y problema actua. Desarrollo Rural Libro Blanco de la Agricultura y el Desarrollo Rural, Ministerio Agricultura Pesca y Alimentación, Madrid, Spain. $\quad$ Retrieved March $1, \quad 2013$ from http://www.magrama.gob.es/es/ministerio/servicios/informacion/plataforma-de-conocimiento-para-el-medi o-rural-y-pesquero/biblioteca-virtual/libros-blancos/

Alcon, F., Pedrero, F., Martin Ortega, J., Arcas, N., Alarcon, J. J., \& de Miquel, M. D. (2010). The non-market value of reclaimed wastewater for use in agriculture: a contingent valuation approach. Spanish Journal of Agricultural Research, 8(S2), S187-S196. http://dx.doi.org/10.5424/sjar/201008S2-1361

Anon. (2010). Italy, Spain: Migrants. Rural Migration News-USA, 16(3). Retrieved September 26, 2012, from http://migration.ucdavis.edu/rmn/comments.php?id=1552_0_4_0

Anon. (2011). Spain: Citrus growers demand support. October 25. Retrieved September 28, 2012, from http://www.freshplaza.com/print.asp?id=88083

Anon. (2012a). EU Parliament approves disputed Morocco farm trade deal. EU Business, February 16. Retrieved October 6, 2012, from http://eubusiness.com/news-eu/morocco-farm-trade.f94

Anon. (2012b). Spain: Oranges from Valencia flood the net. May 15. Retrieved September 21, 2012, from http://www.freshplaza.com/print.asp?id=96382

Anon. (2012c). Spain: Castellon could lose 6,000 hectares of citrus. July 3. Retrieved September 28, 2012, from http://www.freshplaza.com/print.asp?id=97967

Anon. (2012d). Spain: Horta's farmers change citrus crops for subtropical. July 11. Retrieved September 21, from http://www.freshplaza.com/print.asp?id=97278

Anon. (2012e). Spain: "German pressure to open up Valencia citrus prices unacceptable". September 10. Retrieved September 22, 2012, from http://www.freshplaza.com/print.asp?id=100578

Anon. (2012f). La cosecha de citrícos valencianos sera un 20\% inferior la próxima campaña. Las Provincias-ES, September 3. Retrieved October 21, 2012, from http://www.lasprovincias.es/agencias/20120903/economia/coscha-citricos-valencianos-sera-inferior_20120 9031518.html

Anon. (2012g). El comercio debe 150 millones a los agricultures por de la campaña citrícola. Las Provincias-ES, $\begin{array}{lllll}\text { September } & 20 . & \text { Retrieved } & \text { October } & \text { from }\end{array}$ http://www.lasprovincias.es/v/20120920/economia/comercio-debe-millones-agricultores-20120920.html

Anon. (2012h). El valor de la tierra citrícola cae en 50\% respecto al incio de la crisis económica. Levante EMV-ES, September 26. Retrieved October 21, 2012, from http://www.levante-emv.com/economia/2012/09/26/tierra-citricol-cae-50--respecto-inicio-crisis-economica/ 939029.html

Anon. (2012i). Generalitat sitúa en 3.013.856 toneladas la provisión de cosecha citrícola para esta campaña, un 4,9\% menos. 20 Minutos-ES, October 3. Retrieved October 21, 2012, from http://www.20minutos.es/noticia/1607011/0/

Atmospheric Science Data Center - ASDC (2012). Surface meteorology and solar energy - Available Tables: Sueca, ES; Sacramento, USA; Fresno, USA; Bakersfield, USA. National Aeronautics and Space Administration, Langley (VA), USA. Retrieved from http://eosweb.larc.nasa.gov

Ayuntamiento de Valencia. (2004). Biocompost. Technical Final Report of LIFE Project LIFE00 ENV/E/ 000555. October 30. Retrieved October 9, 2012, from http://www.eco-rice.net/miscelanea/descargas/02/003.pdf

Beede, R. H., Kallsen, C. E., Holtz, B. A., Ferguson, L., Klonsky, K. M., \& de Moura, R. L. (2008). Sample costs to establish and produce pistachios: San Joaquin Valley - South, low volume irrigation. University of California Cooperative Extension, Davis (CA), USA. 
Beltrán Esteve, M., Picazo Tadeo, A. J., \& Reig Martínez, E. (2012). What makes a citrus farmer go organic? Empirical evidence from Spanish citrus farming. WPAE-2012-5. Economía Aplicada II, Universitat de València, Valencia, Spain.

Bolens, L. (1972). L'eau et l'irrigation dd'après les traités d'agronomie analous au moyen-âge (XI'-XII ${ }^{\mathrm{e}}$ siècles). Options Mediterranéennes, 16, 65-77.

Bonny, S. (2006). Organic farming in Europe: Situation and prospects. Notre Europe - FR, November 15. Retrieved October 25, 2012, from http://www.notre-europe.eu/fileadmin/IMG/pdf/Bonny_Agribio-EN.pdf

Caballero, P., de Miquel, M. D., \& Fernández Zamudio, M. A. (2011). Los costes de producción en los cítricos. Análisis y posibles actuaciones empresariales. Vida Rural, No. 328 (May 26).

Calatayud i Giner, S. (1989). L'expansió citrícola Valencia. Producció I propietat de la terra a la Ribera del Xúquer (1850-1930). Recerques, 22, 95-115.

Carrasco, J. (2012). La campaña citrícola arranca entre la amenaza de Marruecos y los impagos. Economia Digital-ES, September 5. Retrieved October 21, from http://www.economiadigital.es/valencia/mobile-viewer.php?IDN=2012_09_28090

CBI. (2006). The fresh fruit and vegetables market in the EU. Centre for the Promotion of Imports from Developing Countries, Rotterdam, Netherland. Retrieved March 11, 2012, from http://www.cbi.eu

Ciaccia, C., Di Bartolomeo, E., Calabretta, M. L., Intrigliolo, F., Tittarelli, F., \& Canali, S. (2008). Quality assessment of citrus-processing industry waste compost for organic and conventional farming. Proc. Second Scientific Conference of the International Society of Organic Agriculture Research (ISOFAR), Modena, Italy, June 18-20.

Connell, J. H., Krueger, W. H., Buchner, R. P., Niederholzer, F., DeBuse, C. J., Klonsky, K. M., \& de Moura, R. L. (2012). Sample costs to establish an orchard and produce almonds: Sacramento Valley, micro-sprinkler irrigation. University of California Cooperative Extension, Davis (CA), USA.

Daly, C. (2002). Development of a commercial scale composting plant in Colusa County. Final report of CSU Chico Foundation Project No. ARI 69225, July. Chico State University, Chico (CA), USA.

Day, K. R., Klonsky, K. M., \& de Moura, R. L. (2009). Sample costs to establish and produce processing peaches: July and August harvested varieties, San Joaquin Valley - South. University of California Cooperative Extension, Davis (CA), USA.

DG Environment. (2009). The future of subsidy payments for organic farming. European Commission DG Environment News Alert, Issue 161, July 23.

Duncan, R., Hasey, J., Norton, M., Klonsky, K. M., \& de Moura, R. L. (2011). Sample costs to establish and produce processing peaches: cling and freestone extra-early harvested varieties, Sacramento Valley and San Joaquin Valley. University of California Cooperative Extension, Davis (CA), USA.

European Central Bank. (2013). Reference Exchange Rate. http://sdw.ecb.europa.eu/browse.do?node=2018794)

European Commission - EC. (1999). Council Regulation (EC) No. 1257/1999 of 17 May 1999 on support for rural development from the European Agricultural Guidance and Guarantee Fund (EAGGF) and amending and repealing certain Regulations.

European Commission - EC. (2007). Council Regulation (EC) No. 834/2007 of 28 June 2007 on organic production and labeling of organic products and repealing Regulation (EEC) No. 2092/91.

European Commission - EC. (2010). An analysis of the EU organic sector. June. Directorate-General for Agriculture and Rural Development, Brussels, Belgium.

FAOSTAT. (2012). Orange production, prices and trade - Spain, 2001-2010. Food and Agriculture Organization of the United Nations. Rome, Italy. Retrieved September 20, 2012, from http://faostat.fao.org

Ferguson, L., Krueger, W. H., Connell, J. H., Klonsky, K. M., \& Livingston, P. (2009). Sample costs to produce table olives: Manzanillo variety in the Sacramento Valley,drip irrigation. University of California Cooperative Extension, Davis (CA), USA.

Foundation for Science, Technogly and Civilisation - FSTC. (2012). Muslim Contribution to Spanish Agriculture. Retrieved from www.muslimheritage.com 
Garrido, S. (2007). The "Anticalifornia" family farming, prices and quality product in the Spanish citrus industry (1840-1936). Documentos de trabajo DT-AEHE N 0701. Asociación española de Historia Ecónomica, Madrid, Spain.

Gasque, M., Granero, B., Turegano, J. V., \& Gonzalez Altozano, P. (2010). Regulated deficit irrigation effects on yield, fruit quality and vegetative growth of 'Navelina' citrus trees. Spanish Journal of Agricultural Research, 8(S2), S40-S51. http://dx.doi.org/10.5424/sjar/201008S2-1347

Generalitat Valenciana - GVA. (2010a). Valencian Citrus fruit: Mediterranean freshness on your table. Retrieved $\begin{array}{lll}\text { September } 21, & 2012, & \text { from }\end{array}$ http://www.agricultura.gva.es/web/c/document_library/get_file?uuid=b96d0613-6b75-45c1-a6cd-a398b316 $3 \mathrm{dc} 7 \&$ groupId $=16$

Generalitat Valenciana - GVA. (2010b). Informe del Sector Agrario Valenciano, 2009. November 30. Retrieved $\begin{array}{llll}\text { September } 25, & 2012, & \text { from }\end{array}$ http://www.agricultura.gva.es/web/c/document_library/get_file?uuid=c819d5be-5f06-44de-a58b-1c0090fee bd1\&groupId=16

Generalitat Valenciana-GVA. (2011). Superficies por municipios 2011: València. Retrieved September 30, 2012, from

http://www.agricultura.gva.es/web/c/document_library/get_file?uuid=7c2fa6ac-a56f-448d-b6db-91821f4d5 f4b\&groupId=16

Glick, T. F. (1970). Irrigation and Society in Medieval Valencia. Harvard University Press, Cambridge (MA), USA. Chapters 9 and 13.

Holtz, B. A., Duncan, R. A., Verdegaal, P. S., Klonsky, K. M., \& de Moura, R. L. (2007). Sample costs to produce organic almonds: San Joaquin Valley - North, sprinkler irrigation. University of California Cooperative Extension, Davis (CA), USA.

Instituto Valenciano de Estadistica - IVE. (2012). Superficies y producciones anuales de cultivo, 2006-2010. Retrieved September 25, from http://www.ive.es

International Labour Organization - ILO. (2013). Labour Statistics. Retrieved December 10, 2013, from http://www.ilo.org/global/statistics-and-databases/lang--en/index.htm

International Monetary Fund - IMF. (2010). World Economic Outlook Database. International Monetary Fund, $\begin{array}{llllll}\text { Washington (DC), } \quad \text { USA. } & \text { Retrieved } & \text { October } & \text { 22, }\end{array}$ http:/www.imf.org/external/pubs/ft/weo/2010/02/weodata/index.aspx

Iranzo, M., Cañizares, J. V., Roca-Pérez, L., Sainz-Pardo, I., Mormeneo, S., \& Boluda, R. (2004). Characteristics of rice straw and sewage sludge as composting materials in Valencia (Spain). Bioresource Technology, 95, 107-112. http://dx.doi.org/10.1016/j.biortech.2004.01.013

Jánský, J., \& Živělová, I. (2007). Subsidies for the organic agriculture. Agricutural Economics - Czech, 53, 393-402.

Jánský, J., Živělová, I., \& Novak, P. (2004). The influence of state subsidies on the development of organic agriculture in the Czech Republic and in the EU. Agricutural Economics - Czech, 50, 394-399.

Kamp, K. (2008). Turkey set to become 'organic food basket' of Europe. Today's Zamen - TR, September 14. Retrieved December 28, 2009, from http:/www.todayszaman.com/tz-web/

Klonsky, K., \& Tourte, L. (1997). Production practices and sample costs for fresh market organic Valencia oranges: South Coast. University of California Cooperative Extension, Davis (CA), USA.

Lehner, M. (2010). Policies to promote organic agriculture. Corpus - DK, November 18. Retrieved October 6, 2012 ,

from http://www.scp-knowledge.eu/sites/default/files/KU_show\%20case\%20Orangic_Agriculture.pdf

Lillywhite, R. D., Keeling, C., Courtney, P., Lampkin, N., Pearce, B., Rayns, F., ... Williams, A. (2012). Assessing the economic, environmental and social characteristics of UK farming systems. Workshop 6.1. Proc. $10^{\text {th }}$ European International Farming Systems Association (IFSA) Symposium, Aarhus, Denmark, July 1 $-4$.

Luu, H. M., Vu, T. K., \& Watanabe, T. (2002). Improvement of soil fertility by rice straw manure. Omonrice, 10, $79-86$. 
Mendoza, C. (2001). Immigrant employment in Spanish farming: The case of the Girona fruit sector. Rural Migration News-USA, 7(1). Retrieved September 26, 2012, from $\mathrm{http}: / /$ migration.ucdavis.edu/cf/comments.php?id=40_0_2_0

Modesto, A., Burguera, D., Wong, A., \& Navarro, E. (2005). A new and sustainable approach for straw disposal in the Albufera de Valencia Nature Reserve (Sueca). Proc. $14^{\text {th }}$ European Biomass Conference Paris, France, October 17-21.

Morton, J. (1987). Orange. In J. F. Morton, Fruits of warm climates. J. F. Morton, Miami (FL), USA. pp. 134-142.

Navarro, E., \& Wong, A. (2013). Assessment of energy production options in lieu of orange cultivation in Ribera Baixa. Paper submitted for peer review.

Nettier, B., Dufour, A., Chabrat, S., \& Madelrieux, S. (2012). Conversion to organic farming and consequences on work organisation and work perception. Workshop 6.3. Proc. 10 ${ }^{\text {th }}$ European International Farming Systems Association (IFSA) Symposium, Aarhus, Denmark, July 1-4.

Norton, M., Hasey, J., Duncan, R., Klonsky, K. M., \& de Moura, R. L. (2011). Sample costs to establish and produce processing peaches: cling and freestone late harvested varieties, Sacramento Valley and San Joaquin Valley. University of California Cooperative Extension, Davis (CA), USA.

O’Connell, N. V., Kallsen, C. E., Klonsky, K. M., \& de Moura, R. L. (2009). Sample costs to establish an orange orchard and produce oranges: Navels and Valencias; San Joaquin Valley - South, low volume irrigation. University of California Cooperative Extension, Davis (CA), USA.

Padilla, B., \& Peixoto, J. (2007). Latin American immigration to Southern Europe. Migration Information Source-USA, June 28. Retrieved September 26, 2012, from http://www.migrationinformation.org/Feature/display.cfm?ID=609

Peris Moll, E. M., \& Juliá Igual, J. F. (2003). Effects of Regulation (EEC) 2078/92 on citrus growing in Calabria (Italy) and the Region of Valencia (Spain). Spanish Journal of Agricultural Research, 3, 34-42.

Peris Moll, E. M., \& Juliá Igual, J. F. (2006). Long-term feasibility of sustainable citrus-farming systems in the region of Valencia, Spain. Journal of Food Distribution Research, 37, 139-147.

Peris Moll, E. M., Juliá Igual, J. F., \& Balasch Parisi, S. (2005). Estudio de las diferencias de costes de producción del cultivo de naranjo convencional, ecológico e integrado en la Comunidad Valenciana mediante el análisis factorial discriminante. Economia Agraia y Recursos Naturales, 5, 69-87.

Picazo Tadeo, A. J., \& Reig Martínez, E. (2005). Calculating shadow wages for family labour in agriculture: An analysis for Spanish citrus fruit farms. Cahiers d'économie et sociologie rurales, 75, 5-21.

Ribal, J., Sanjuan, N., Clemente, G., \& Loreto Fenollosa, M. (2009). Medición de la ecoeficiencia en procesos productivos en el sector agrario. Caso de studio sobre producción de cítricos. Economia Agraia y Recursos Naturales, 9, 125-148

Roca-Pérez, L., Arevalo, J., \& Boluda, R. (2004). The influence of C/N ratio, moisture and pH on the aerobic microbial activity of rice straw and sewage sludge blends. Proc. $11^{\text {th }}$ RAMIRAN Conference, Murcia, Spain, October 6-9.

Ruiz Sanchez, M. C., Domingo, R., \& Castel, J. R. (2010). Review: Deficit irrigation in fruit trees and vines in Spain. Spanish Journal of Agricultural Research, 8(S2), S5-S20. http://dx.doi.org/10.5424/sjar/201008S2-1343

Swagemakers, P., Domínguez García, L., \& Simón Fernández, X. (2012). Constituting context: organic farming and the provision of public goods. Workshop 6.3. Proc. $10^{\text {th }}$ European International Farming Systems Association (IFSA) Symposium, Aarhus, Denmark, July 1 -4.

Takele, E., \& Mauk, P. (1998). Establishment and production costs: Valencia oranges, Coachella Valley, Riverside County. University of California Cooperative Extension, Davis (CA), USA.

Tran, T. N. S., Luu, H. M., Cao, N. D., Tran, T. A. T., \& Nguyen, N. N. (2008). Bioconversion of paddy rice straw and biofertilizer for sustainable rice based cropping system. Omonrice, 16, 57-70.

United States Bureau of Labor Statistics. (2013). Consumer Price Index calculator. Retrieved from http://www.bls.gov/data/inflation_calculator.htm

United States Department of Agriculture - USDA. (2011). EU-27 Citrus Annual Report 2011. GAIN Report Number: SP1128, December 14. 
United States Department of Agriculture - USDA. (2012). EU-27 Citrus Annual Report 2012. GAIN Report Number: SP1242, December 12.

Watson, A. M. (1974). The Arab agricultural revolution and its diffusion, 700-1100. Journal of Economic History, 34, 8-35. http://dx.doi.org/10.1017/S0022050700079602

Wier, M., Andersen, L. M., Millock, K., O’Doherty Jensen, K., \& Rosenkvist, L. (2005). Perceptions, values and behaviour: The case of organic foods. KVL Fredriksberg, Denmark.

Wong, A., \& Hallsworth, A. (2013). Corporate subversion of social justice initiatives in food and agriculture. Journal of Administration and Governance, in press.

\section{Copyrights}

Copyright for this article is retained by the author(s), with first publication rights granted to the journal.

This is an open-access article distributed under the terms and conditions of the Creative Commons Attribution license (http://creativecommons.org/licenses/by/3.0/). 